We thank Professor T. Matsuo (Kyushu University) for helpful discussions on the charge separation in the micellar systems.

Received, 15th February 1982; Com. 161

\section{References}

1 R. H. Abeles, R. F. Hutton, and F. H. Westheimer, J. Am. Chem. Soc., 1957, 79, 712.

2 D. J. Creighton and D. S. Sigman, J. Am. Chem. Soc., 1971, 93, 6314; F. M. Martens, J W. Verhoeven, R. A. Gase, U. K. Pandit, and Th. J. de Boer, Tetrahedron, 1978, 34, 443; J. W. Bunting and S. Sindhuatmadja, J. Org. Chem., 1981, 46, 4211.

3 L. C. Kurz and C. Frieden, J. Am. Chem. Soc., 1975, 97, 677; 1980, 102, 4198; Biochemistry, 1977, 16, 5207.

4 J. J. Steffens and D. M. Chipman, J. Am. Chem. Soc., 1971, 93, 6694.

5 D. J. Creighton, J. Hajdu, G. Mooser, and D. S. Sigman, J. Am. Chem. Soc., 1973, 95, 6855; J. Hajdu and D. S. Sigman, ibid. 1976, 98,6060; A. Ohno, H. Yamamoto, and S. Oka, J. Am. Chem. Soc., 1981, 103, 2041; A. Ohno, T. Shio, H. Yamamoto, and S. Oka, ibid., 1981, 103, 2045; S. Shinkai, T.
Ide, H. Hamada, O. Manabe, and T. Kunitake, J. Chem. Soc., Chem. Commun., 1977, 848; S. Shinkai, T. Tsuno, and O. Manabe, Chem. Lett., 1981, 1203; A. Ohno, H. Yamamoto, T. Okamoto, S. Oka, and Y. Ohnishi, ibid., 1978, 65; for comprehensive reviews, see R. J. Kill and D. A. Widdowson, Bioorg. Chem., 1978, 4, 239; D. S. Sigman, J. Hajdu, and D. J. Creighton, ibid., p. 385.

6 A. K. Colter, G. Saito, F. J. Sharom, and A. P. Hong, J. Am. Chem. Soc., 1976, 98, 7833; Can. J. Chem., 1977, 55, 2741.

7 P. van Eikeren, D. L. Grier, and J. Eliason, J. Am. Chem. Soc., $1979,101,7405$.

8 D. M. Chipman, R. Yaniv, and P. van Eikeren, J. Am. Chem. Soc., 1980, 102, 3244.

9 A. Ohno and N. Kito, Chem. Lett., 1972, 369; C. C. Lai and A. K. Colter, J. Chem. Soc., Chem. Commun., 1980, 1115.

10 R. A. Hood, R. H. Prince, and K. A. Rubinson, J. Chem. Soc., Chem. Commun., 1978, 300.

11 K. Kano, K. Takuma, K. Ikeda, D. Nakajima, Y. Tsutsui, and T. Matsuo, Photochem. Photobiol., 1978, 27, 695; M. S. Tunuli and J. H. Fendler, J. Am. Chem. Soc., 1981, 103, 2507; P.-A. Brugger, P. P. Infelta, A. M. Braun, and M. Grätzel, ibid., 1981, 103, 320.

12 T. Kunitake, J. Macromol. Sci., Chem., 1980, A13, 587.

\title{
The Metabolism of the Diterpenoid Hydrocarbon, ent-Trachylobane, by Gibberella fujikuroi and the $X$-Ray Structure Determination of the Methyl Ester of Trachylobagibberellin $\mathrm{A}_{40}$
}

\author{
Braulio M. Fraga, antonio G. Gonzalez, Melchor G. Hernandez, James R. Hanson, ${ }^{b}$ and \\ Peter B. Hitchcock ${ }^{b}$ \\ a Instituto de Productos Naturales del C.S.I.C., Carretera La Esperanza 2, La Laguna, Tenerife, Spain \\ b School of Molecular Sciences, University of Sussex, Brighton, Sussex, BN1 9QJ, U.K.
}

The diterpenoid pentacyclic hydrocarbon, ent-trachylobane, has been shown to be converted by Gibberella fujikuroi to trachylobagibberellin $\mathrm{A}_{40}$ using spectroscopic and $X$-ray methods.

A number of pentacyclic diterpenoids are known ${ }^{1-3}$ which possess the ent-trachylobane carbon skeleton (1). entTrachylobane (1) bears a considerable structural resemblance to the tetracyclic diterpenoid, ent-kaur-16-ene (2) which is the parent biosynthetic hydrocarbon of the gibberellin plant hormones. ${ }^{4}$ Despite a lack of substrate specificity in the later stages of gibberellin biosynthesis in Gibberella fujikuroi, the enzyme systems responsible for the immediate oxidation of ent-kaurene show some features of structure specificity. Thus ent-kaur-15-ene (isokaurene) accumulates ${ }^{5}$ in the gibberellin deficient d-5 mutant of maize and is not readily further metabolized whilst 16,17-epoxy-ent-kaurane displaces entkaur-16-ene and inhibits its oxidative modification by Gibberella fujikuroi. ${ }^{6}$ The formation of ent-kaur-16-ene has been suggested to be a limiting step in gibberellin plant hormone biosynthesis. Despite the occurrence of several structurally similar series of polycyclic diterpenoids related to ent-kaur-16-ene, nevertheless all (more than 60) the naturally occurring gibberellin plant hormones isolated so far belong to the ent-kaurene series. Consequently it was of interest to examine the metabolism of the diterpenoid hydrocarbons of the same enantiomeric series such as ent-trachylobane by G. fujikuroi. The conversion of ent-trachylobanic acid (3) into pentacyclic analogues of the gibberellins by a mutant (B141a) of $G$. fujikuroi which is blocked for gibberellin biosynthesis between ent-kaurenal (4) and ent-kaurenoic acid (5) has

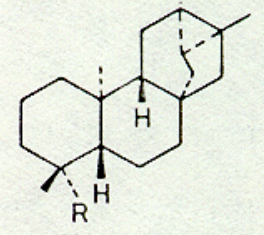
(1) $\mathrm{R}=\mathrm{Me}$
(3) $\mathrm{R}=\mathrm{CO}_{2} \mathrm{H}$
(7) $\mathrm{R}=\mathrm{CH}_{2} \mathrm{OH}$

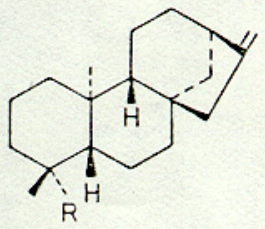

(2) $\mathrm{R}=\mathrm{Me}$

(4) $\mathrm{R}=\mathrm{CHO}$

(5) $\mathrm{R}=\mathrm{CO}_{2} \mathrm{H}$

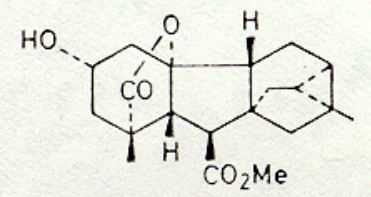

(6)

been reported ${ }^{7}$ and reveals the lack of structure specificity in the formation of the gibberellins once the 19-carboxylic acid is formed. 


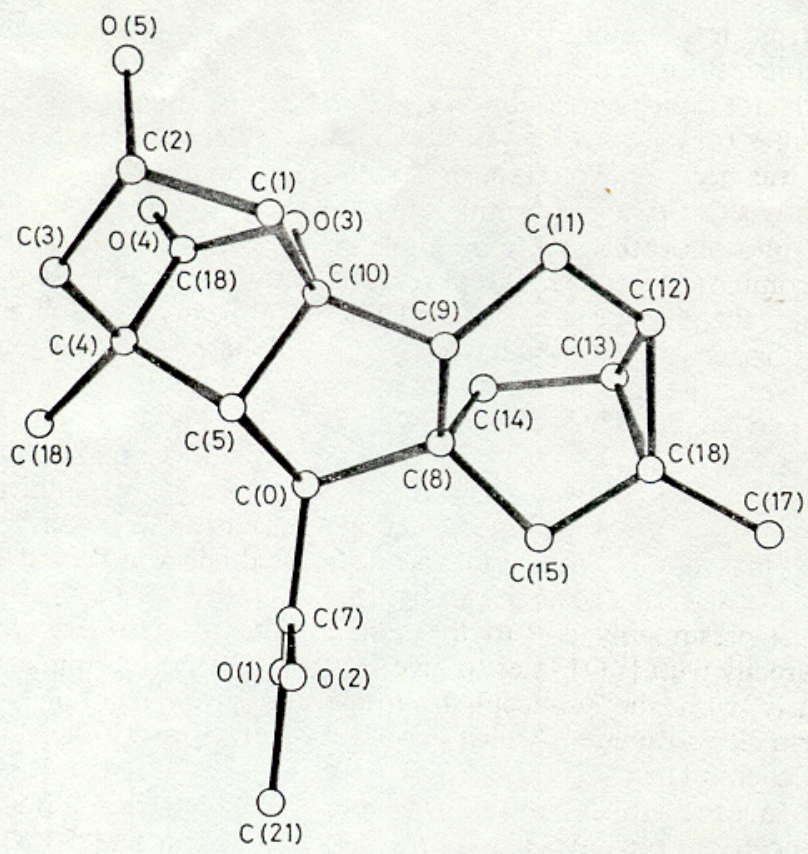

Figure 1. Molecular structure of trachylobagibberellin $\mathrm{A}_{40}$ methyl ester (6).

The transformation of ent-trachylobane (1) by the 'wildtype' Gibberella fujikuroi (ACC 917) was examined in shake culture in the presence of AMO-1618 which inhibits ${ }^{8}$ kaurene synthetase and hence the formation of endogenous kaurenoid metabolites. The yield of trachylobane transformation products was low. The acidic metabolites were separated as their methyl esters. The ${ }^{1} \mathrm{H}$ n.m.r. spectrum of the major component, $\mathrm{C}_{20} \mathrm{H}_{26} \mathrm{O}_{5}$ (Found: 346.1752 ; calc. 346.1724 ), m.p. $227-$ $229^{\circ} \mathrm{C}$, showed a $\mathrm{CH}(\mathrm{OH})$ signal as a triplet, $\delta 4.26(\mathrm{~J} 4 \mathrm{~Hz})$. The 5-H and $6-\mathrm{H}$ signals were co-incident $(\delta 2.49)$ whilst the cyclopropane signals ( $\mathrm{H}-12$ and $\mathrm{H}-13, \delta 0.6$ and 0.9$)$ showed little perturbation ${ }^{9}$ which might be assigned to adjacent hydroxylation thus suggesting that the hydroxyl group was located on the $\alpha$-face of ring A. The complete structure (Figure 1) was determined by $X$-ray analysis of the methyl ester (6). The metabolite was thus trachylobagibberellin $\mathrm{A}_{40} \cdot{ }^{10}$

Since this metabolite, which represents a relatively unusual hydroxylation pattern, was not reported ${ }^{7}$ in the study of enttrachylobanic acid, the metabolism of ent-trachyloban-19-ol(7) by the 'wild-type' strain of G. fujikuroi was also examined. The acidic metabolites were again separated by chromatography of their methyl esters. This afforded a mixture of the esters of trachylobagibberellins $A_{9}, A_{25}, A_{13}, A_{7}, A_{40}$, and possibly $A_{47}$.
These were identified partly by their ${ }^{1} \mathrm{H}$ n.m.r. spectra and by comparison of their mass spectra with published $\mathrm{data}^{10}$ for the natural gibberellins.

Thus the fungal gibberellin pathway is able to handle, albeit in low yield, abnormal but naturally-occurring diterpenoid hydrocarbons. However, it is interesting to note that the dominant $2 \alpha$-hydroxylation differs from the more common $3 \beta$-hydroxylation found in the natural gibberellins of $G$. fujikuroi.

Crystal data: $\mathrm{C}_{20} \mathrm{H}_{26} \mathrm{O}_{5}, M=346.4$, orthorhombic, space group $P 22_{1} 22_{1}, a=8.298(2), b=10.612(5), c=20.152(9) \AA$, $U=1774.5 \AA^{3}, Z=4, D_{\mathrm{c}}=1.30 \mathrm{~g} \mathrm{~cm}^{-3}, F(000)=744$, Mo- $K_{\alpha}$ radiation, $\lambda=0.71069 \AA, \mu=1.0 \mathrm{~cm}^{-1}$. The data were measured on an Enraf-Nonius CAD-4 diffractometer whilst the structure solution and refinement were carried out on a PDP $11 / 34$ computer using the Enraf-Nonius structure determination package. The structure was solved from 1006 reflections and refined to $R=0.063$ and $R^{\prime}=0.069$. $\dagger$

We thank Professor Panizzo for a gift of trachylobane diterpenoids. This work was supported in part by a grant awarded by the C.A.I.C.T. (Ministry of Education, Spain).

Received, 3rd March 1982; Com. 234

\section{References}

1 G. Hugel, L. Lods, J. M. Mellor, D. W. Theobald, and G. Ourisson, Bull. Soc. Chim. Fr., 1965, 2882.

2 J. St. Pyrek, Tetrahedron, 1970, 26, 5029.

3 A. G. Gonzalez, J. L. Breton, B. M. Fraga, and J. G. Luis, Tetrahedron Lett., 1971, 3097.

4 B. E. Cross, R. H. B. Galt, and J. R. Hanson, J. Chem. Soc., 1964, 295.

5 P. Hedden and B. O. Phinney, Phytochemistry, 1979, 18, 1475.

6 J. R. Hanson, K. P. Parry, and C. L. Willis, Phytochemistry, 1980, 19, 2323.

7 J. R. Bearder, J. MacMillan, A. Matsuo, and B. O. Phinney, J. Chem. Soc., Chem. Commun., 1979, 649.

8 B. E. Cross and P. L. Myers, Phytochemistry, 1969, 8, 79; M. F. Barnes. E. N. Light, and A. Lang, Planta, 1969, 88, 172

9 A. Arnone, R. Mondelli, and J. St. Pyrek, Org. Magn. Reson., $1979, \mathbf{1 2}, 429$.

10 I. Yamaguchi, M. Miyamoto, H. Yamana, N. Murofushi, N. Takahashi, and K. Fujita, J. Chem. Soc., Perkin Trans. 1, $1975,996$.

$\dagger$ The atomic co-ordinates for this work are available on request from the Director of the Cambridge Crystallographic Data Centre, University Chemical Laboratory, Lensfield Road, Cambridge, CB2 1EW. Any request should be accompanied by the full literature citation for this communication. The structure factor table is available as Supplementary Publication No. SUP 23347 ( $6 \mathrm{pp}$ ) from the British Library Lending Division. For details of how to obtain this material, see Notice to Authors No. 7, J. Chem. Soc., Dalton or Perkin Trans., Index Issues.

\title{
Synthesis of Adenosine $5^{\prime}\left[(R) \alpha-{ }^{17} \mathrm{O}\right]$ Triphosphate
}

\author{
Gordon Lowe, ${ }^{* a}$ Gaynor Tansley, a and Paul M. Cullis ${ }^{b}$ \\ a The Dyson Perrins Laboratory, Oxford University, South Parks Road, Oxford OX1 3QY, U.K. \\ b Department of Chemistry, Leicester University, Leicester LE1 7RH, U.K.
}

Adenosine $5^{\prime}[(S) \alpha$-thio $]$ triphosphate is converted predominantly into adenosine $5^{\prime}[\gamma-180]$ triphosphate by bromine in $\left[{ }^{18} \mathrm{O}\right]$ water, but adenosine $5^{\prime}\left[(S) \alpha\right.$-thio]diphosphate gives adenosine $5^{\prime}\left[(R) \alpha-{ }^{17} O\right]$ diphosphate on treatment with bromine in [ $\left.{ }^{17} \mathrm{O}\right]$ water which can be converted enzymically into adenosine $5^{\prime}\left[(R) \alpha-{ }^{17} \mathrm{O}\right]$ triphosphate.

A method has been developed for the analysis of the chirality of $\left[{ }^{16} \mathrm{O},{ }^{17} \mathrm{O},{ }^{18} \mathrm{O}\right]$ phosphate esters, ${ }^{1}$ which makes possible the determination of the stereochemical course of not only phosphokinases, ${ }^{2}$ phosphomutases, ${ }^{3}$ phosphatases, ${ }^{4}$ and phospho- 
